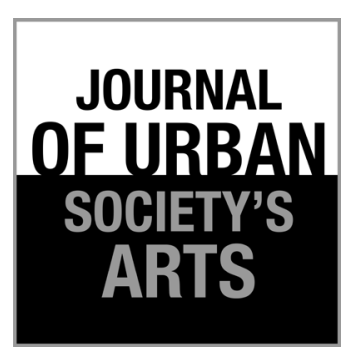

Volume 4 Nomor 2, Oktober 2017: 61-70

\section{Komodifikasi Agama pada Media Sinema sebagai Strategi Jualan Industri Perfilman Indonesia}

\section{Dwi Haryanto dan Bambang Aris Kartika}

Staf Pengajar Fakultas Ilmu Budaya Universitas Jember

Jl. Kalimantan No.37, Sumbersari, Jember, Kabupaten Jember, Jawa Timur 68121

Tlp.087836587057,E-mail: haryantodwex@gmail.com

\begin{abstract}
ABSTRAK
Penelitian ini bertujuan untuk membuktikan adanya relevansi secara tekstualitas antara konten agama sebagai isu atau tematik komoditas dengan konten film biopik yang menjadi obyek material maupun untuk mengetahui dan mengungkapkan relevansi teks-teks berbasis konsepsi teks agama dalam film biopik sebagai bagian dari tipetipe komodifikasi agama di tren genre film Indonesia. Melalui film Sang Pencerah, bagaimana konsepsi agama yang dikembangkan oleh KH Ahmad Dahlan keluar dari konsepsi Islam puritan dalam menjalankan Dakwah Islamiyah. Pembaharuan yang dilakukan oleh KH Ahmad Dahlan melalui dekonstruksi terhadap konsepsi puritanisime terlihat dari teks-teks film yang menghadirkan $\mathrm{KH}$ Ahmad Dahlan mengkoreksi posisi sholat secara radikal kearah 14 derajat, dakwah melalui musik biola, menggunakan baju dengan model masyarakat eropa, berjualan batik dan melarang sesajen. Bahkan konsekuensinya, $\mathrm{KH}$ Ahmad Dahlan dimusuhi oleh sesama kiai atau ulama dan mushola yang didirikannya sempat dibakar. Konten cerita yang bersinggungan dengan sejarah KH Ahmad Dahlan dan keyakinanya dengan konsepsi agama dan identitas menjadi teks-teks konten yang menarik menjadi komoditas film. Sejarah KH Ahmad Dahlan dengan konsepsi perjuangan agamanya dikomodifikasi oleh para sineas, baik sutradara, penulis naskah, maupun produser, menjadi barang tontonan yang kemudian dijual kepada penonton. Aspek ekonomi menjadi lebih utama dibandingkan dengan alasanalasan ideologi agama. Konten-konten ini menarik dari sisi cerita sebuah film. Karena film adalah industri hiburan yang menarik penonton, maka konten film juga sangat menentukan. Konsepsi agama kembali menjadi basis praktik komodifikasi.
\end{abstract}

Kata kunci: komodifikasi; komoditas; teks film, film biopik

\section{ABSTRACT}

Religious Commodity on Cinema Media as a Strategy for Selling Film Industry of Indonesia. This study aims to prove the textual relevance between religious content as an issue or thematic commodity with biopic film content that becomes material object or to know and express the relevance of texts based on the conception of religious texts in biopic film as part of the types of religious commodification in trend of Indonesian film genre. Through a film entitled Sang Pencerah, how the religion conception developed by KH Ahmad Dablan by way out of puritan Islamic conception in conductthe islamic values. KH Ahmad Dahlan renewed through the deconstruction of puritanism conception seen in the text of the film that presents KH Ahmad Dahlan which corrects the position of prayers radically to 14 degrees, dakwah through violin music, using clothes with european models, selling batik and banning offerings. As a consequence, KH Ahmad Dablan was enraged by his fellow Islamic religious leaders and the mosque he founded was burned. The contents of the story that intersect with the history of KH Ahmad Dahlan and his beliefs with the conception of religion and identity become an interesting text to be used as filmcommodity. The history of KH Ahmad Dablan with the conception of his religious struggle commodified by the filmmakers, both directors, writers, and producers, a spectacle that is then sold to the audience. The economic aspect becomes more important than the reasons for religious 
ideology. These contents are interesting from the side of the moviestory, because the movie is an entertainment industry that attracts viewers, then the movie content is also very decisive. Religion conception is again the basis of commodification practice.

Keywords: commodification; commodity; film text; biopic film

\section{Pendahuluan}

Film merupakan salah satu produk unggulan di era industri kreatif. Karena salah satu subsektor dalam industri kreatif adalah kegiatan kreatif yang terkait dengan kreasi, produksi video, film, dan jasa fotografi, serta distribusi rekaman video, film dan hasil fotografi. Termasuk di dalamnya penulisan skrip, dubbing film, sinematografi, sinetron, dan eksibisi film. Potensi industri kreatif terkait dengan perfilman sangat besar sekali. Sumber-sumber kreatif yang menjadi konten film di Indonesia memungkinkan bagi para sineas dan pelaku industrui keratif film untuk memproduksi film. Dari tema-tema alam, sastra dan novel, sejarah, biografi, true story atau kisah nyata, petualangan hingga kebudayaan bahkan agama.

Kini industri kreatif perfilman Indonesia mengalami perspektif baru dengan mengangkat tema-tema historis biografi yang direpresentasikan dalam visualisasi biografi tokoh sejarah sebagai komodifikasi oleh para sineas Indonesia. Di antara film-film biopic terdapat film yang mengusung tema-tema tokoh yang memiliki keterkaitan dengan agama. Artinya, agama yang identik dengan tokoh ulama besar menjadi isi atau konten teks film dari sisi naratif maupun visual-sinematik, seperti film Sang Pencerah dan Sang Kiai yang mewakili kelompok Islam, sedang film Soegija mewakili kelompok katolik. Namun, sejatinya film Sang Kiai dan Soegija sangat kental nuansa nasionalisme yang dibawa oleh tokoh-tokoh Hasyim Asy'ari dan Monsingur Albertus Soegijapranata. Sementara dalam film Sang Pencerah unsur pembaharuan dalam konsepsi agama Islam sangat kuat sebagai teks film, baik dari sisi naratif dan visual-sinematik.

Film sejarah biografi religiusitas yang menampilkan hubungan antara tokoh agama dan konten agama tidak saja bagian dari historicalmemory (ingatan sejarah) dan collective memory (ingatan kolektif) bagi bangsa Indonesia, melainkan juga menjadi bagian dari perilaku kapitalisme dengan menjadikan fakta historis menjadi komodifikasi. Oleh karena itu, perlu dilakukan kajian terhadap film-film biografi sejarah tokoh (biopics) untuk mengetahui sejauhmana fakta-fakta historis yang diadaptasi dan direkonstruksi ke dalam bentuk film, baik dari sisi teks, strategi visual, kepentingan maupun metode produksi film tersebut mampu menjadi produk komodifikasi sebagai produk komoditas.

Menurut Irwansyah (2009:20-21) membuat film ditujukan untuk mencari uang. Oleh karena itu, film yang lahir mestilah yang disukai pembeli, yakni penonton film. Membuat film harus dengan hitung-hitungan untung rugi. Tidak boleh membuat film yang hanya mungkin ditonton sedikit orang. Justru bagaimana membuat film yang bakal ditonton sebanyak mungkin orang. Beberapa film biopic maupun yang bersetting dengan tematema sejarah juga mendapat apresiasi yang tinggi di kalangan penonton Indonesia. Artinya, film biopic maupun epik sejarah dan agama tetap bisa menjadi sumber menarik bagi produksi film atau sinema di Indonesia. Berikut daftar table data jumlah penonton film Indonesia berbasis historis biografi dan tematik epic sejarah dari tahun 2009 s.d. 2016 (Tabel 1).

Dengan demikian, data tersebut menunjukkan sejauh mana praktik komodifikasi terhadap film sejarah biografi (biopic) yang memiliki keterkaitan dengan tokoh agama maupun epik sejarah, dan tematik sejarah dijadikan sebagai strategi jualan bagi penonton Indonesia, terutama dari sisi komodifikasi agama. Hakikat film merupakan produk budaya populer yang memang diorientasikan untuk kepentingan pasar (bisnis-uang) dan kebutuhan propaganda sebagai bagian dari komunikasi massa. Artinya, berlangsung suatu bentuk strategi media dengan melakukan rekayasa komodifikasi, 
terutama komodifikasi agama dan tokoh yang memiliki pengaruh besar dalam konsepsi relasi kuasa, khususnya berlatarbelakang agama.

\section{Metodologi Penelitian}

Dalam memahami dan mengkaji film-film biopic dengan konten teks-teks yang dikemas sebagai komodifikasi agama yang menjadi obyek kajian, maka metode yang digunakan adalah metode kualitatif deskriptif. Karena untuk memahami film perlu dilakukan pendekatan subjektif yang bersifat tekstual-kontekstual. Pendekatan subjektif merujuk pada deskriptif dengan melakukan analisis interpretatif, yakni peneliti melakukan tafsir terhadap temuan data dari sudut fungsi dan peran kaitannya dengan unsur lain.

Adapun objek data adalah teks naratif dialog dan teks visual yang terdiri atas beberapa shot-shot dalam sekuens-sekuens sebagai unsur struktural naratif film. Data terkait dengan faktafakta historis religius dan konsepsi agama yang kemudian disinkronisasi dengan alur peristiwa cerita yang tercermin dalam teks dialog maupun teks visual. Kemudian dilakukan teknik analisis secara interpretatif, setelah sebelumnya meneliti dokumen-dokumen maupun referensi-referensi terkait dengan fakta-fakta sejarah yang melingkupi kehidupan dan peristiwa-peristiwa penting yang dilakukan oleh tokoh dalam film maupun kosnepsi keagamaan dan konten agama. Dengan demikian akan diperoleh kejelasan fakta sejarah tokoh maupun konten agama yang akan disinkronisasikan dengan fakta-fakta dalam teks naratif maupun visual film.

\section{Hasil dan Pembahasan}

\section{Sinopsis dan Struktur Naratif Film}

Film secara struktural memiliki daya tarik pada sisi unsur intrinsik, seperti pemain atau aktor dan aktris, cerita, tema, adegan aksi, efek visual, ilustrasi musik, setting, acting, sudut pandang dan pergerakan kamera, atau yang lainnya. Dengan demikian untuk bisa memahami film, maka diperlukan pemahaman terlebih dahulu dari sisi otonom film yang terbentuk atas adanya unsurunsur pembentuk film.

Pratista (2008:1-2) mengatakan bahwa secara umum film dapat dibagi atas dua unsur pembentuk film, yakni unsur naratif dan unsur sinematik. Unsur naratif berhubungan dengan aspek cerita atau tema film. Setiap cerita pasti memiliki unsurunsur seperti tokoh, masalah, konflik, lokasi, waktu serta lainnya. Seluruh elemen tersebut membentuk unsur naratif secara keseluruhan dan saling berinteraksi serta berkeseinambungan membentuk jalinan peristiwa yang terikat dengan aturan hokum kausalitas (logika sebab-akibat). Sementara unsur sinematik merupakan aspek-aspek teknis dalam produksi sebuah film, yaitu mise en scene, sinematografi, editing, dan suara. Seluruh unsur sinematik tersebut saling terkait, mengisi, serta berkesinambungan satu sama lain untuk membentuk unsur sinematik secara keseluruhan.

\begin{tabular}{rclr}
\hline No & Tahun Edar Film & \multicolumn{1}{c}{ Judul Film } & Jumlah Penonton \\
\hline 1 & 2009 & Merah Putih & 611.573 orang \\
2 & 2010 & Sang Pencerah & 1.206 .000 orang \\
3 & 2010 & Darah Garuda (Merah Putih II) & 407.426 orang \\
4 & 2012 & Habibie \& Ainun & 4.488 .889 orang \\
5 & 2012 & Soegija & 459.465 orang \\
6 & 2013 & Soekarno: Indonesia Merdeka & 960.071 orang \\
7 & 2013 & Sang Kiai & 220.419 orang \\
8 & 2014 & Merry Riana: Mimpi Sejuta Dolar & 715.671 orang \\
9 & 2015 & Di Balik 98 & 684.727 orang \\
10 & 2015 & Guru Bangsa: Tjokroaminoto & - orang \\
11 & 2015 & Jenderal Soedirman & 181.687 orang \\
12 & 2016 & Surat dari Praha & 59.502 orang \\
\hline
\end{tabular}

Tabel 1. Data jumlah penonton film Indonesia berbasis historis biografi dan tematik sejarah tahun 2009-2016.

(Sumber: www.filmindonesia.or.id, diakses tanggal 14 Februari 2016) 
Dalam struktur naratif cerita film Sang Pencerah dapat dipahami dari pemetaan data teksteks yang berupa sekuens-sekuens film. Sekuens film merupakan kronologis peristiwa dari rangkaian cerita sebab akibat yang membentuk plot cerita. Konten cerita dalam susunan struktur naratif inilah yang menjadi komoditas film yang menarik bagi penonton. Keterjalinan antara cerita, permasalahan atau konflik, setting peristiwa dan waktu, relasi antartokoh tercermin dari struktur naratif film. Dalam film Sang Pencerah terdiri atas beberapa sekuens-sekuens, antara lain:

\section{KH Ahmad Dahlan masa kecil}

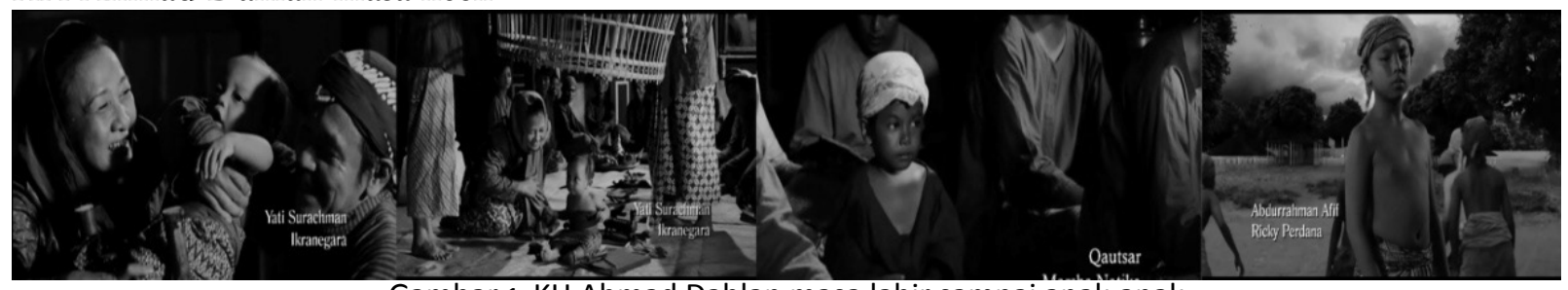

Gambar 1. KH Ahmad Dahlan masa lahir sampai anak-anak

(Screen Capture Film Sang Pencerah TC. 00.00.52.15-00.02.08.05)

2. KH Ahmad Dahlan berangkat haji dan belajar agama di Mekkah

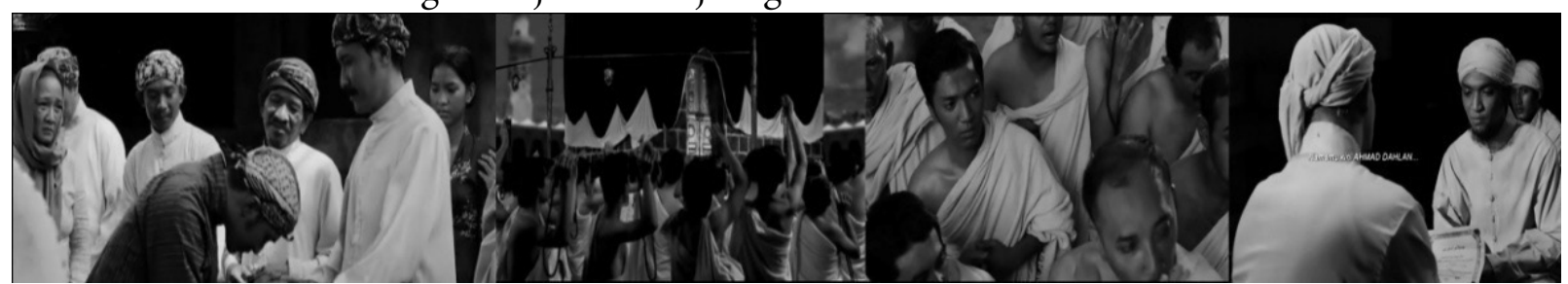

Gambar 2. KH Ahmad Dahlan berangkat naik haji dan belajar agama di Mekkah

(Screen Capture Film Sang Pencerah TC. 00.09.50.05-00.12.15.10)

3. KH Ahmad Dahlan pulang menjadi pengusaha batik

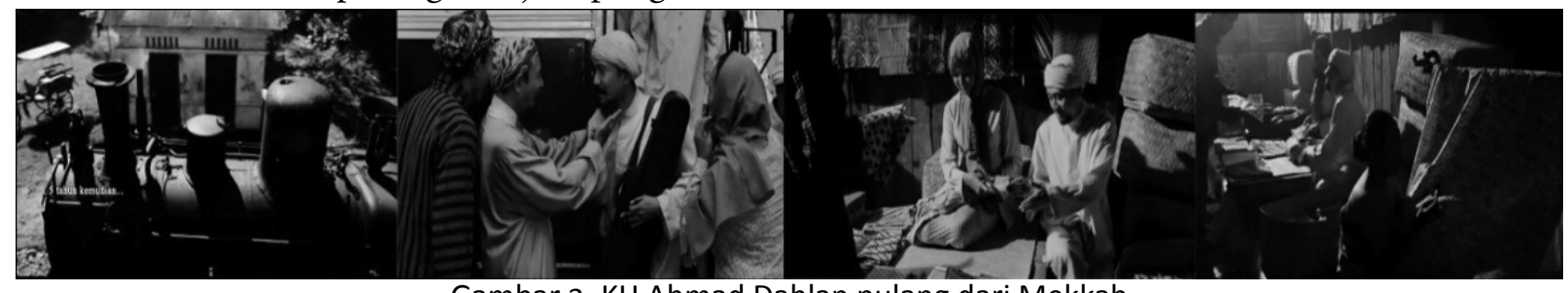

Gambar 3. KH Ahmad Dahlan pulang dari Mekkah

(Screen Capture Film Sang Pencerah TC. 00.12.19.00-00.15.04.00)

4. KH Ahmad Dahlan mengkoreksi puritanisme di kalangan umat Islam

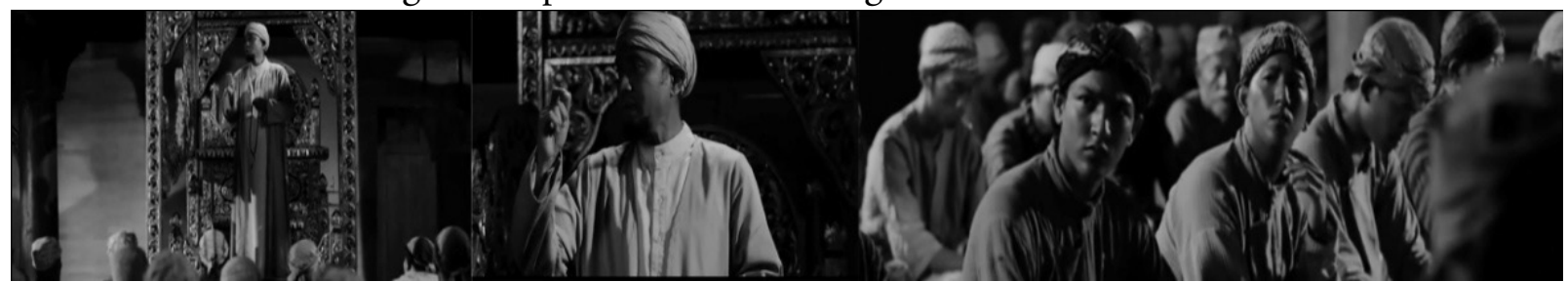

Gambar 4. KH Ahmad Dahlan bersiar agama di kalangan umat Islam

(Screen Capture Film Sang Pencerah TC. 00.16.32.00-00.18.07.15)

5. KH Ahmad Dahlan berseteru dengan beberapa ulama keraton

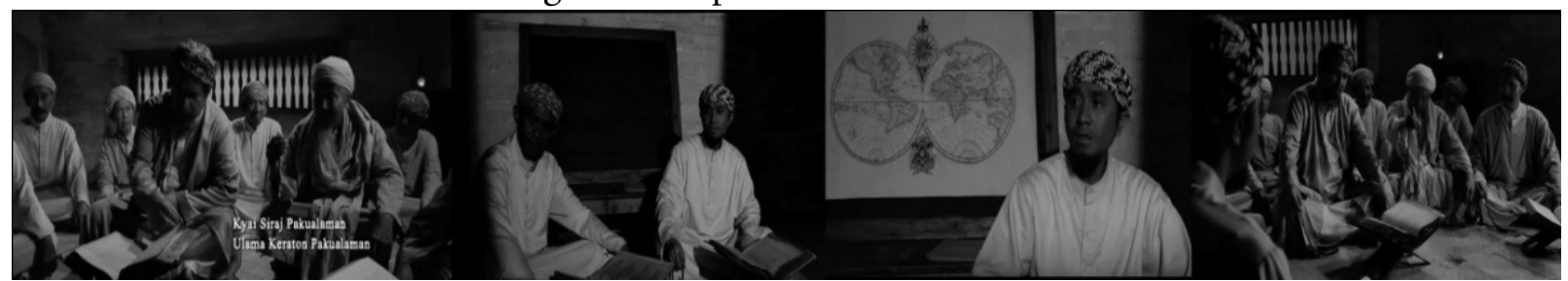

Gambar 5. KH Ahmad Dahlan bberseteru dengan beberapa ulama keraton

(Screen Capture Film Sang Pencerah TC. 00.27.59.17-00.31.00.15) 
6. KH Ahmad Dahlan mengkoreksi posisi sholat ketika menghadap kiblat

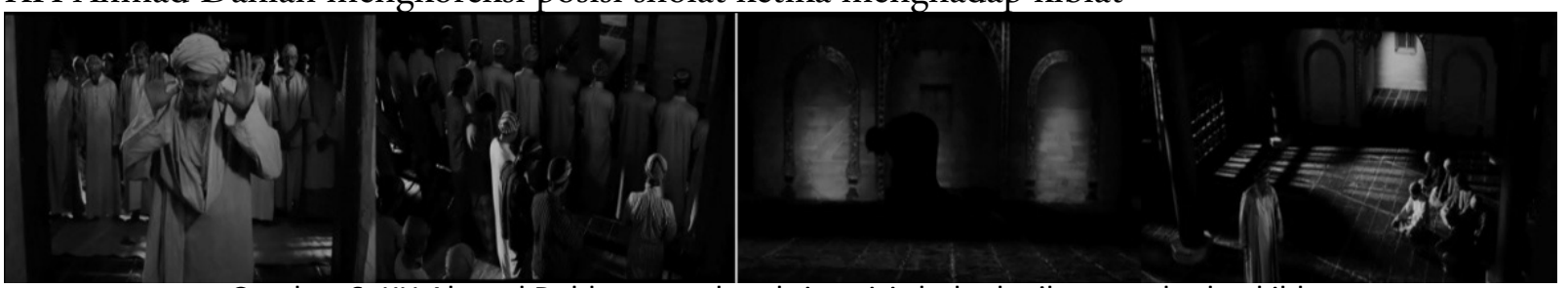

Gambar 6. KH Ahmad Dahlan mengkoreksi posisi sholat ketika menghadap kiblat

(Screen Capture Film Sang Pencerah TC. 00.31.00.16-00.34.40.15)

7. KH Ahmad Dahlan mendirikan masjid dan kemudian masjidnya dibakar

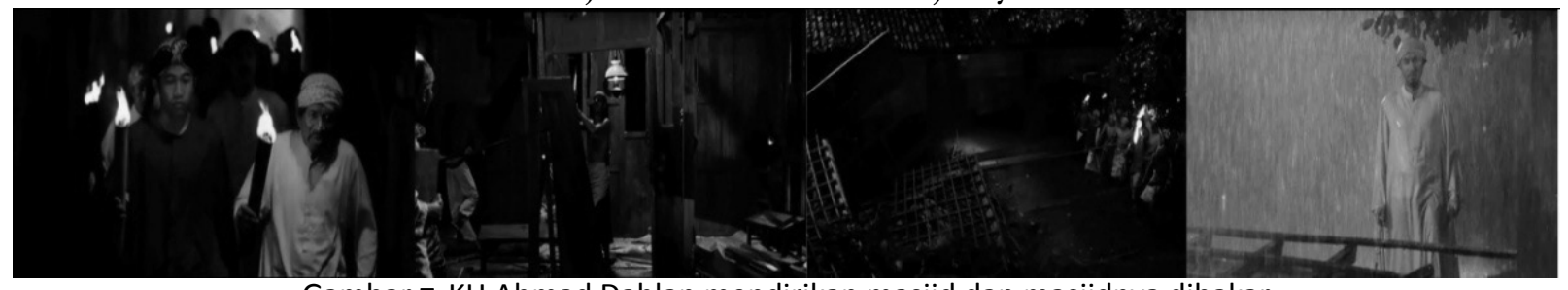

Gambar 7. KH Ahmad Dahlan mendirikan masjid dan masjidnya dibakar

(Screen Capture Film Sang Pencerah TC. 00.39.46.17-00.44.43.15)

8. KH Ahmad Dahlan mendirikan sekolah Muhammadiyah

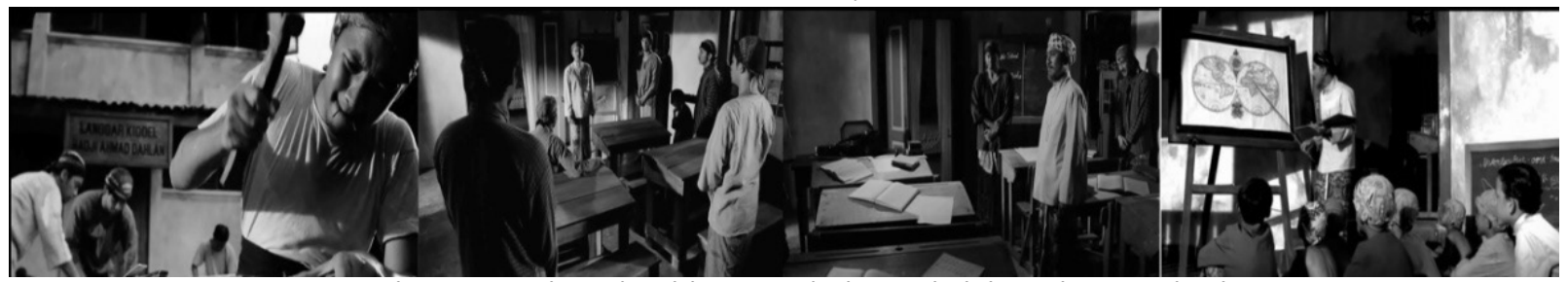

Gambar 8. KH Ahmad Dahlan mendirikan sekolah Muhammadiyah

(Screen Capture Film Sang Pencerah TC. 01.16.34.18-01.31.46.09)

Susunan sekuens-sekuens film menunjukkan adanya keterkaitan konten antara sosok biografi $\mathrm{KH}$ Ahmad Dahlan dengan konsepsi agama. Komoditas agama dan perjuangan KH Ahmad Dahlan menjadi konten keseluruhan jalinan plot cerita film Sang Pencerah. Artinya, agama dan sejarah biografi menjadi komoditas teksteks film. Dari susunan struktur naratif inilah, penonton menjadi tahu bagaimana perjuangan $\mathrm{KH}$ Ahmad Dahlan dalam melakukan dakwah Islamiyah. Sikap pembaharuan terhadap agama Islam muncul dan tercermin dalam konten teks film Sang Pencerah. Hal inilah yang kemudian menjadi identitas dari diri $\mathrm{KH}$ Ahmad Dahlan. Bagaimana KH Ahmad Dahlan dengan keyakinan Islamnya merebut ruang kuasa agama yang selama ini dihegemoni oleh para ulama puritan dan ulama keraton. Pertarungan merebut kebenaran menurut konsepsi Islam yang dien dan yang sebenarnya sesuai tuntunan Al-Qur'an dan Al Hadits adalah daya tarik utama dari struktur naratif film Sang Pencerah.

\section{Historiografi Biografi dan Sumber Film: Basis Produksi}

Terkait dengan film biopik, maka aspek bahasan dalam ilmu sejarah yang sangat relevan adalah aspek sejarah naratif dan sejarah biografi. Sejarah naratif terkait dengan kaidah maupun cara bertutur cerita, sedangkan sejarah biografi lebih kepada subjek film yang berupa cerita perjalanan hidup seseorang. Menurut Ali (2005:35-36) bahwa sejarah bukan semata-mata rangkaian fakta belaka, tetapi sejarah adalah sebuah cerita. Cerita adalah penghubung antara sejarah serba objek dan serba subjek. Sejarah serba objek adalah kenyataan yang sudah menjadi kejadian peristiwa, yakni kejadian peristiwa yang benar-benar sudah terjadi, sedangkan sejarah serba subjek adalah penuturan cerita sejarah. Isi cerita sejarah adalah riwayat manusia yang betul-betul terjadi di zaman lampau. Dengan menggunakan dua perspektif aspek bahasan dari ilmu sejarah ini, maka film dokudrama biopik benar-benar mampu merekonstruksi peristiwa 
sebagai bentuk dari representasi fakta sejarah. Menurut Haryanto (2015:190), representasi yang seakan-akan langsung dan otentik dalam bentuk gambar bergerak merupakan kekuatan utama film.

Terkait dengan perspektif sejarah naratif dan sejarah biografi, film sebagai produk budaya massa memiliki hubungan dengan isi cerita sejarah yaitu peristiwa yang dialami oleh tokoh pada zaman lampau. Karena dalam sejarah semua peristiwa secara persis diceritakan kapan terjadi. Hal ini yang membedakan dengan mitos (Kuntowijoyo, 2013:7). Kontribusi dari ilmu sejarah terhadap eksistensi film adalah penulisan sejarah atau historiografi. Dalam penulisan sejarah, aspek kronologis sangat penting (Kuntowijoyo, 2013:80). Aspek kronologis juga sangat berperan penting dalam penyusunan isi cerita film, khususnya film bergenre sejarah biografi tokoh (dokudrama). Karena penyusunan isi cerita harus berdasarkan pada plot atau alur cerita yang bersifat kronologis atas peristiwa-peristiwa yang terjadi dan dialami oleh tokoh. Dan alur atau plot peristiwa tersebut tetap harus berdasarkan fakta sejarah yang kemudian direkonstruksi ke atas layar film atau sinema.

KH Ahmad Dahlan alias Muhammad Darwis lahir di Kauman, Yogyakarta pada tahun 1869. Kisah perjuangan KH Ahmad Dahlan awalnya terpengaruh oleh gerakan pembaruan Islam terutama di Mesir dan Arab Saudi. Karena desakan orang tuanya, $\mathrm{KH}$ Ahmad Dahlan harus belajar di Mekkah dan berhaji. Di Mekkah, KH Ahmad Dahlan juga mempelajari berbagai pemikiran pembaruan dalam Islam. Langkah awal pembaruan Islam, KH Ahmad Dahlan bergabung dengan Sarekat Boedi Oetomo yang diketuai oleh Dr. Wahidin Sudirohusodo, dan organisasi Jamiat Khair. Untuk melaksanakan pembaruan Islam, $\mathrm{KH}$ Ahmad Dahlan mendapat dukungan dari berbagai pihak. Namun demikian, dalam mendirikan Muhammadiyah pada tanggal 18 November 1912. KH Ahmad Dahlan mengalami berbagai rintangan. Salah satunya adalah ditolaknya permohonan izin mendirikan Muhammadiyah. KH Ahmad Dahlan tetap berjuang, sehingga pada 1914 permohonan itu dikabulkan dengan diterbitkannya Surat Ketetapan Pemerintah No.81 tanggal 22 Agustus 1914 yang diketuai oleh KH Ahmad Dahlan.
Dengan berdirinya Muhammadiyah, kemajuan dalam berbangsa sangat terasa.

Data diatas merupakan data literature yang diambil dari buku dengan Judul $\mathrm{KH}$ Ahmad Dahlan Biografi Singkat (1869-1923). Film Sang Pencerah merupakan salah satu karya film karya sejarah (histiriografi) namun hal itu tidak dapat dilihat dari bentuknya, melainkan dilihat dari metode penggarapannya. Bentuk dapat jadi apapun bisa buku, film dan novel. Hal yang terpenting ketika sebuah karya terutama film dikatakan karya historiografi atau bukan haruslah disimak dari proses penggarapannya. Dikalangan sejarawan jika suatu karya akan disebut historiografi jika memiliki kaidah-kaidah yang sudah disepakati. Kaidah-kaidah tersebut adalah metode sejarah. Metode ini merupakan tahap-tahap penelitian sejarah yang diawali dengan tahap pengumpulan data (heuristik), kritik ekstern (otentisitas), kririk intern (validitas), intepretasi dan terakhr penulisan atau histiriografi. Dengan demikian setelah dikaitkan dengan data-data teks yang berasal dari buku KH Ahmad Dahlan Biografi Singkat (18691923) dengan data visual yang terdapat dalam film Sang Pencerah membuktikan bahwa film tersebut bersumber dari penulisan sejarah (historiografi) Biografi KH Ahmad Dahlan.

\section{Media Sinema: Komunikasi Massa atas Agama}

Dalam komunikasi massa, film atau sinema merupakan komoditas publik yang sangat strategis untuk mendulang keuntungan kapital dari prinsip ideologi kapitalisme. Karena fungsi komunikasi massa menurut Jay Black dan Frederick C. Whitney (dalam Nurudin, 2014:64) antara lain: (1) to inform (menginformasikan), (2) to entertain (memberi hiburan), (3) to persuade (membujuk), dan (4) transmission of the culture (transmisi budaya). Berdasarkan fungsi komunikasi massa yang dikemukakan oleh Jay Black dan Frederick C. Whitney, maka film sangat sesuai diklasifikasikan sebagai produk dari komunikasi massa. Hal ini dilatarbelakangi bahwa film memberikan informasi, memberi hiburan, membujuk, dan media transmisi budaya, meskipun film merupakan karya seni yang mengandung konsep dan fungsi- 
fungsi kemanusiaan, pendidikan, sosial, ekonomi, ideologi, kebudayaan, sejarah, lingkungan maupun politik.

Dalam konteks fungsi film sebagai bagian dari komunikai massa, maka film Sang Pencerah menjadikan konten agama Islam sebagai komoditas teks film yang kemudian disajikan kepada penonton sebagai produk tontonan untuk hiburan. Selain memberikan informai mengenai konsepsi dakwah islamiyah, baik dari $\mathrm{KH}$ Ahmad Dahlan melalui organisasi Muhammadiyah, dalam film tersebut juga menyampaikan pesan-pesan moral religisusitas kepada penonton. Ada proses memproduksi makna, bahwa dalam menegakkan konsepsi agama memerlukan perjuangan dan keikhlasan hati dan batin. Agama menuntun umat manusia untuk berbuat kebaikan kepada sesama manusia dengan keihlasan dan keridloan.

Selain itu juga terdapat proses transmisi budaya, bagaimana kebudayaan Islam yang dibangun melalui film Sang Pencerah yaitu kebudayaan masyarakat Yogyakarta pada masa lalu. Pola-pola dakwah islamiyah dapat dijadikan sebagai transformasi kebudayaan kepada penonton yang terdiri atas perlbagai etnik dan budaya. Melalui film penonton bisa memahami dan memaknai kebudayaan daerah masing-masing, baik dalam pola pikir dan pola perilaku maupun dalam kehidupan keagamaan. Di Yogyakarta, pola patron klien antara ulama atau kiai dengan umatnya justru bersifat equal. Artinya, terjadi saling belajar antara kiai dengan santrinya. Dan para kiai tidak memaksakan ajarannya kepada santrinya, sebagaimana ditunjukkan oleh sikap KH Ahmad Dahlan dalam film, yang menyerahkan sepenuhnya sikap untuk mengikuti ajaran Islam kepada santrinya. Santrinya dibebaskan untuk memilih mengikuti dirinya atau ulama lainnya dan tanpa pernah menjudge atau menjelekkan ulama lainnya.

Konten agama yang tercermin dalam teks film Sang Pencerah merupakan bentuk komoditas yang menjadikan komunikasi sebagai produk media, yaitu media sinema kepada publik atau penonton. Agama dalam konteks produk budaya massa menjadi alat bagi terbangunnya jalinan komunikasi yang bersifat massa namun tetap tidak meninggalkan kepentingan komoditas hiburan.
Ideologi pasar tetap menjadi orientasi meskipun secara artefak film memiliki fungsi sebagai media komunikasi massa. Keuntungan kapital tetap yang menajdi utama, meskipun dalam film juga terangkum makna-makna dan pesan moral yang berisi nilai-nilai pendidikan, kebudayaan, sosial, dan kehidupan.

\section{Komodifikasi Agama dalam Film Biopik: konten Teks dan Pencapaian Tematik}

Vincent Mosco (dalam Ibrahim dan Akhmad, 2011:17) mendefinisikan komodifikasi sebagai "proses mengubah barang dan jasa, termasuk komunikasi, yang dinilai karena kegunaannya, menjadi komoditas yang dinilai karena apa yang akan mereka berikan di pasar." Komodifikasi adalah proses transformasi barang dan jasa yang semula dinilai karena nilai gunanya, (misalnya, cerita untuk berkomunikasi atau berbagi pengalaman), menjadi komoditas yang bernilai karena ia bisa mendatangkan keuntungan di pasar setelah dikemas menjadi buku novel maupun produksi drama untuk penyiaran komersial. Sementara Sementara itu I Gede Mudana (dalam Atmadja, 2010:viii) menyatakan, "komodifikasi secara umum adalah menjadikan sesuatu yang pada awalnya bukan dagangan menjadi produk yang dapat dijual-belikan. Tujuannya adalah fulus semata. Komodifikasi menyangkut seluruh bidang ekonomi, mulai dari produksi, distribusi, dan konsumsi. Kenyataannya, saat ini, bukan saja benda-benda biasa, tempat, kesakralan, rahasia, bahkan diri dan tubuh sekalipun dikomodifikasi."

Film telah menjadi komoditas-komoditas budaya yang berkelip dan dengan kepentingan kapitalisme. Film dalam konteks kapitalisme ini diartikan sebagai bentuk dari komodifikasi. Hal ini senada dengan apa yang dikemukakan oleh Barker (dalam Sasono, 2011:58) bahwa komodifikasi adalah proses ketika objek, kualitas, dan penanda diubah menjadi komoditas yang tujuan utamanya adalah untuk dijual di pasar. Mosco (2009:129) menyatakan, "Commodification is the process of transforming use value into exchange values." (komodifikasi adalah proses perubahan nilai guna menjadi nilai tukar). Lebih 
jauh Mosco menyatakan, "Communication process and technologies contribute to the general process of commodifikcation in the economy as a whole." (proses dan teknologi komunikasi telah berkontribusi pada proses umum komodifikasi dalam ekonomi secara keseluruhan) (2009:130).

Film yang baik dalam konteks media sinema adalah film yang mampu merepresentasikan kenyataan sehari-hari sedekat mungkin (mimetik), terutama film live action (film yang dimainkan tokoh nyata) sekaligus film yang bercerita (film naratif). Proses representasi ini diawali dengan cara pembuat film melihat masyarakatnya. Artinya, pembuat film harus memiliki perspektif. Kemudian dilakukan rekonstruksi. Proses rekonstruksi dimulai saat menulis skenario hingga film selesai diproduksi (Irwansyah, 2009:12-13).

Film Sang Pencerah oleh Hanung Bramantyo, sebagai produk sinema dengan tema historis tokoh agama memang dikemas dalam bentuk visualisasi struktur narasi film mewakili situasional zaman pada saat itu. Dan, masyarakat pada era pascakolonial dirasa perlu untuk menemukan muatan-muatan makna dan nilai dari penggambaran kontribusi ideologi maupun identitas kebangsaan tokoh agama, yaitu KH Ahmad Dahlan dalam skala nasional yang menjadi penanda dan petanda dari bangsa dan negara melalui struktur narasi film. Hal ini merupakan aset historis dalam kaitannya dengan industri media meskipun dalam ranah produk budaya populer. Artinya, sejarah biografi $\mathrm{KH}$ Ahmad Dahlan dan konsepsi agama merupakan produk budaya popular yang dikemas dalam film untuk kemudian dijual kepada penonton melalui strategi-strategi pemasaran, seperti melalui eksibisi di gedung-gedung bioskop dengan mengambil momen pas hari raya Idul Fitri, menjual kepada perusahaan televisi, maupun dalam bentuk VCD dan DVD. Jelas sekali konsep ideologi pasar tetap menjadi orientasi, meskipun substansi struktur naratif film sarat dengan muatan agama dan biografi KH Ahmad Dahlan.

Trend film biografi Indonesia di era tahun 2000-an mencerminkan adanya upaya komodifikasi histori tokoh agama dengan mendekonstruksi terhadap trend sinema Indonesia yang didominasi

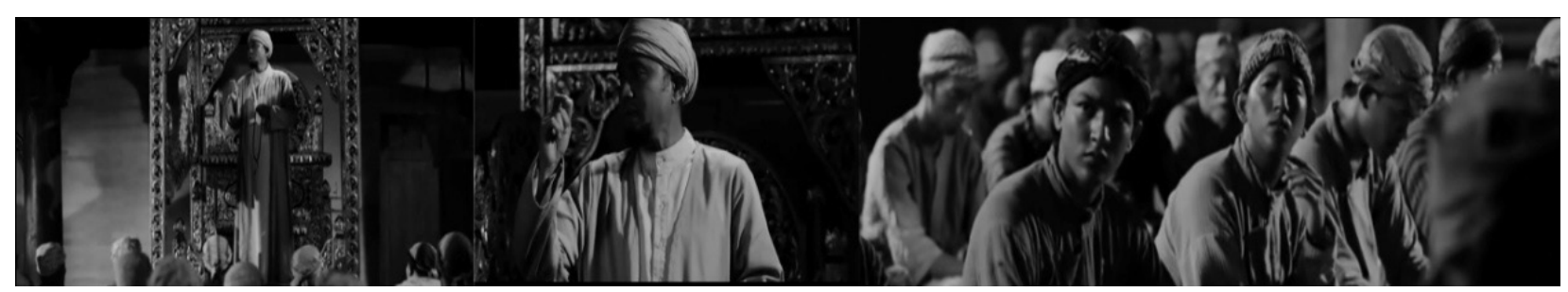

Gambar 9. KH Ahmad Dahlan bersiar agama di kalangan umat Islam

(Screen Capture Film Sang Pencerah TC. 00.16.32.00-00.18.07.15)

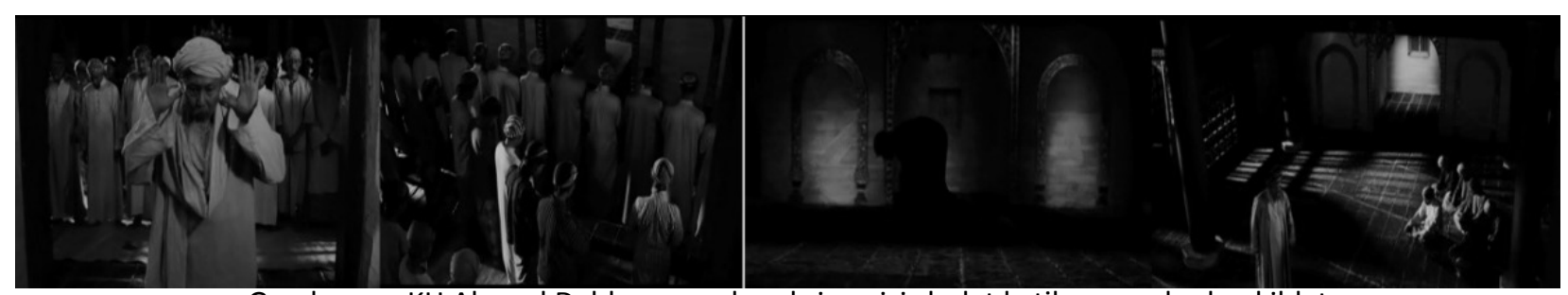

Gambar 10. KH Ahmad Dahlan mengkoreksi posisi sholat ketika menghadap kiblat

(Screen Capture Film Sang Pencerah TC. 00.31.00.16-00.34.40.15)

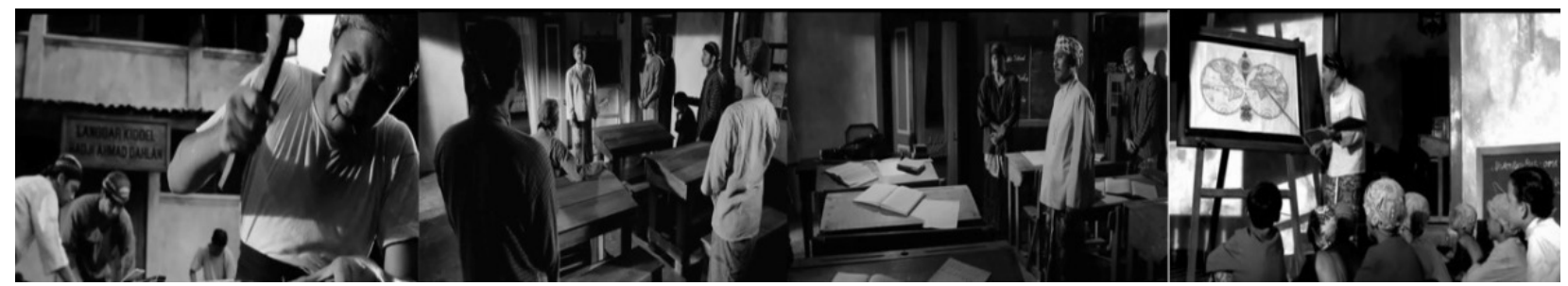

Gambar 11. KH Ahmad Dahlan mendirikan sekolah Muhammadiyah

(Screen Capture Film Sang Pencerah TC. 01.16.34.18-01.31.46.09) 
oleh narasi film komedi, action/laga, drama, horor, maupun remaja. Contohnya adalah film Sang Pencerah karya sutradara Hanung Bramantyo (Kisah Biografi K.H. Ahmad Dahlan), Soegija karya sutradara Garin Nugroho (Kisah Biografi Monsingur Albertus Soegijapranata, SJ), dan Sang Kiai karya sutradara Rako Prijanto (Kisah Biografi K.H. Hasyim Asy'ari). Pada tahun 2014, meskipun film drama mendominasi layar film Indonesia selama setengah tahun terakhir, namun film komedi justru mendapatkan perolehan penonton tertinggi. Dari 7.356.830 penonton sampai dengan Juni 2014, film dengan genre komedi memperoleh 2.437.982 penonton atau setara dengan 33,13 persen dari keseluruhan perolehan penonton nasional sepanjang Januari - Juni 2014 (Ramadani, 2014).

Mosco (2009) menyatakan bahwa salah satu tipe dari komodifikasi yang penting bagi komunikasi massa adalah komodifikasi isi. Komodifikasi isi menjadi pusat perhatian kajian ekonomi politik media dan komunikasi. Ketika pesan atau isi komunikasi diperlakukan sebagai komoditas, ekonomi politik cenderung memusatkan kajian pada konten (content) media dan kurang pada khalayak media dan tenaga kerja yang terlibat dalam produksi media, seperti dalam produksi media sinema. Komodifikasi isi juga memiliki relevansi dengan komodifikasi nilai yang menjelma dalam bentuk proses komodifikasi yang menganut dalam dunia pendidikan dan agama (Ibrahim dan Akhmad, 2014:23). Artinya, isi media dan nilai isi media memiliki orientasi timbal balik yang kritis terkait dengan komodifikasi agama. Pesan atau isi terkait agama maupun perilaku dari tokoh agama dalam konteks media sinema dijadikan sebagai komoditas jualan yang sejalan dengan industri media dan budaya popular maupun melibatkan kosepsi media sebagai aparatur dalam komunikasi massa.

\section{Simpulan}

Apapun bentuk atau genre film, orientasi ekonomi dan ideologi pasar jelas menjadi tujuan utamanya. Kepentingan ekonomi menjadikan para sineas mencari dan menemukan strategi konten teks film menjadi komoditas yang bisa dijual sebagai produk hiburan. Salah satu yang menarik penonton adalah dengan menjadikan konten agama dan sejarah biografi tokoh agama sebagai produk komoditas. Melalui praktik komodifikasi, agama yang selama ini bersifat private dan relasi kuasa antara Tuhan dengan manusia, ulama dengan umat telah diposisikan sebagai produk komoditas yang bisa dijual kepada penonton. Pemilihan konten teks film menjadi sisi yang menentukan dari sisi tema maupun estetika sinematografi untuk dikomodifikasi menjadi film.

Di tengah industri perfilman, maka film-film berbasis agama dan sejarah biografi tokoh agama secara ekonomi jelas sudah terukura dari sisi keuntungan capital. Karena kedekatan emosional antara penonton dengan tokoh maupun karena alasan agama mampu dimanipulasi oleh para sineas agar datang ke geudng bioskop untuk menonton. Warga Muhammadiyah pasti akan menonton film Sang Pencerah, padahal umat Muhammadiyah ribuan bahkan jutaan. Dengan demikian sudah dapat diperkiraan keuntungan finansialnya karena sudah terkalkulasi basis penontonnya. Oleh karena itu, film dalam konteks industri media, menjadikan segala sesuatu, termasuk agama menjadi komoditas melalui praktik komodifikasi.

\section{Kepustakaan}

Atmadja, Nengah Bawa. 2010. Komodifikasi Tubuh Perempuan Joged "Ngebor" Bali. Denpasar: Program Studi Magister dan Doktor Kajian Budaya Universitas Udayana bekerjasama dengan Pustaka Larasan.

Ayawaila, Gerzon R. 2008. Dokumenter Dari Ide sampai Produksi. Jakarta: FFTV-IKJ Press

Budiman, Christian; Abdullah, Irwan; Simatupang, G.R. Lono. 2013. "Retorik dan Makna Ideologi Karya Instalasi dalam Film Opera Jawa Garin Nugroho. RESITAL Jurnal Seni Pertunjukkan. Vol. 14 No. 1 Juni 2013. Halaman 1-8.

Damono, Sapardi Djoko. 2014. Alih Wahana. Jakarta: Editum.

Ernesto, Ari. 2011. Memetakan Kompleksitas Kajian dan Teori Film (Bagian 1). Tersedia dalam http://cinemapoetica.com/mmetakan- 
kompleksitas-kajian-dan-teori-film-bagian-1/ diunduh pada tanggal 20 November 2015.

Haryanto, Ariel. 2015. Identitas dan Kenikmatan Politik Budaya Layar Indonesia. Jakarta: Kepustakaan Populer Gramedia (KPG).

Ibrahim, Idi Subandy dan Akhmad Bachruddin Ali. 2014. Komunikasi dan Komodifikasi Mengkaji Media dan Budaya dalam Dinamika Globalisasi. Jakarta: Yayasan Obor Indonesia.

Ida, Rachma. 2014. Metode Penelitian Studi Media dan Kajian Budaya. Jakarta: Prenada Media Group.

Irwansyah, Ade. 2009. Seandainya Saya Kritikus Film. Yogyakarta: Homerian Pustaka

Kartika, Bambang Aris. 2015. "Komodifikasi Histori dalam Sinema Indonesia. Jurnal Historia. Volume 9, Nomor 1 Juni 2015. Halaman 67-82.

Kuntowijoyo. 2003. Metodologi Sejarah. Edisi Kedua. Yogyakarta: Tiawa Wacana.

Kuntowijoyo. 2008. Penjelasan Sejarah (Historical Explanation). Cetakan Pertama. Yogyakarta: Tiara Wacana.

Metz, Christian. 1974. A Semiotics of the Cinema: Film Language. New York: Oxford University Press.

Mosco, Vincent. 2009. The Political Economy of Communication. Edisi ke-2. London \& New York: Sage

Nurudin. 2014. Pengantar Komunikasi Massa. Cetakan kedua. Jakarta: Rajagrafindo Persada.

Palmer, Richard E. 2016. Hermeneutika Teori
Baru Mengenai Interpretasi. Penerjemah Musnur Hery dan Damanhuri Muhammad. Yogyakarta: Pustaka Pelajar.

Prakosa, Gotot. 1997. Film Pinggiran. Jakarta: FFTV IKJ bekerjasama dengan YLP.

Pratista, Himawan. 2008. Memahami Film. Cetakan Ke II. Yogyakarta: Homerian Pustaka. Ramadani, Deden. 2014. "Catatan Tengah Tahun Film Indonesia 2014. Tersedia di http:// filmindonesia.or.id/article/catatan-tengahtahun-film-indonesia-2014\#.VRC76Y7P7IU diunduh tanggal 24 Maret 2015.

Renier, G.J. Metode dan Manfaat Ilmu Sejarah. Yogyakarta: Pustaka Pelajar

Sasono, Eric. 2011. "Film-film Indonesia Bertema Islam Dewasa Ini: Jualan Agama atau Islamisasi”. Dalam Khoo Gaik Cheng dan Thomas Barker (ed). Mau Dibawa ke Mana Sinema Kita? Beberapa Wacana Seputar Film Indonesia. Penyunting Ekky Imanjaya. Jakarta: Salemba Humanika.

Siswanto, Joko. 1997. "Metode Keilmuan Hermeneutika (Sebuah Pengantar Umum untuk Memahami Hermeneutika sebagai Teori, Filsafat, dan Kritik)”. Makalah disampaikan pada Internship Filsafat Ilmu bagi para Dosen PTN/PTS se Indonesia. Kerjasama Fakultas Filsafat UGM dengan Dirjen Pendidikan Tinggi, Depdikbud Ri. Yogyakarta: 25 September 1997.

Sutopo, H.B. 2002. Metodologi Penelitian Kualitatif. Surakarta: Sebelas Maret University Press. 